\title{
LA ESTÉTICA MUSICAL EN EL MEDIEVO CRISTIANO O UN VIAJE ESTÉTICO A LAS FORMAS MUSICALES GREGORIANAS
}

\author{
Luis Prensa Villegas \\ Conservatorio Superior de Música de Zaragoza
}

\section{RESUMEN}

Hablar de estética musical en el Medievo cristiano es hablar de las condiciones de lo bello en las formas musicales litúrgicas y, en definitiva, de la estética en una música que, con el tiempo, llegará a denominarse «canto gregoriano». Y porque la belleza de una obra musical reside en su forma, recorreremos los elementos que la identifican.

Es, por tanto, un estudio filosófico-estético-poético, que tratará de descubrir las manifestaciones humanas contenidas en este repertorio: la música no es otra cosa que la expresión alegre o dolorida de los sentimientos humanos, porque en ella, igual que en el alma humana, todo tiene cabida.

Palabras clave: Música litúrgica, Humana, Bella, Expresiva, Emocionada.

\section{ABSTRACT}

Speaking about musical aesthetics in the Christian Middle Age is speaking about the conditions of beauty in liturgical musical forms and, ultimately, about aesthetics in a kind that, with the passage of time, would be called «Gregorian chant». And because the beauty of a musical work lies in its form, we will try to discover the human expressions contained in its repertoire: music is nothing more than the joyful or hurtful expression of human feeling because in it, the same as in the human soul, everything could be included.

Key Words: Liturgical music, Human, Beautiful, Expressive, Excited.

\section{INTRODUCCIÓN}

Es harto conocido que la música medieval ha sido objeto de especulación por parte de maestros de la época, que vertieron al papel sus lúcidas lucubraciones filosófico-estéticas en magníficos tratados: Boecio, Hermannus Contractus, Alcuino, San Agustín, Aureliano de Reomé, Remigio de Auxerre, Hucbaldo de St. Amand, Odón de Cluny, Reginón de Prüm... De ellos y de su doctrina ha hecho una magistral exposición Fubini ${ }^{1}$, quien se apresura a decir: «Tanto es así que, si se echa una 
ojeada a las decenas de tratados sobre música escritos desde el Renacimiento carolingio en adelante, no puede uno sustraerse a la sensación de aburrimiento que genera la aparente uniformidad existente en los temas tratados, en las definiciones casi idénticas que calcan los unos de los otros, en los problemas que someten a debate y en las soluciones que ofrecen, cristalizadas siempre, al parecer, en los mismos esquemas». ${ }^{2}$ Cierta es, a nuestro juicio, esta grave aseveración, como lo es también el juicio que emite a continuación, al estudiar al teórico Juan de Garlandia: «Es evidente que, durante el siglo XIV, comienzan a hacer sus primeras apariciones, aunque sea tímidamente, conceptualizaciones acerca de la belleza de la música en tanto que hecho autónomo, belleza que encuentra su única justificación en sí misma: en la belleza pura que los sonidos emiten». ${ }^{3}$

Si comenzamos estas reflexiones citando al maestro Fubini es precisamente porque no queremos provocar el mismo tedio de que habla, en el convencimiento de que este sentimiento es lo más lejano a una reflexión sobre lo bello, al placer provocado por una obra musical. Por ello queremos situar, desde el principio, por dónde va a discurrir nuestra especulación —-mejor, nuestra contemplación - del hecho musical del Medievo cristiano. ${ }^{4}$ Porque hablar de estética musical en esta época es hablar de las condiciones de lo bello en las formas musicales litúrgicas y, en definitiva, de la estética en una música que, con el tiempo, llegará a denominarse «canto gregoriano».

En efecto, una obra de arte puede escrutarse desde distintos puntos de vista. En las obras musicales podriamos estudiar las formas, tratar de determinar su belleza, su perfección o sus defectos; o tratar de descubrir en ellas la expresión de determinadas ideas, la descripción de los sentimientos o pasiones; o la influencia que la música produce, o las emociones que provoca. Todo ello y mucho más es la honda reflexión estética que vamos a abordar.

Ante esta tarea se nos presentan muchos interrogantes: ¿dónde reside la belleza de una obra musical? ¿Cuáles son los caracteres que la hacen bella? ¿Qué sentimientos o pasiones despierta? ${ }_{i}$ Es acaso su forma lo que nos conmueve, o es más bien el mensaje que late en ella? ¿Puede trascender una obra medieval a su tiempo y hacernos conmover hoy, por ejemplo, igual que en el siglo $\mathrm{V}$ ?

Sólo en el disfrute de la obra musical —diríamos más, en su interiorización - podemos encontrar una respuesta razonable a estos y otros interrogantes, dejando antes por sentado que la belleza de la música depende de distintos factores. Habría que acudir aquí a la diferenciación de unas obras de otras, para tratar de descubrir los caracteres que las hace únicas en su composición y únicas en la percepción de intérpretes y de oyentes. Y llegaríamos a la conclusión de que la belleza de una obra musical reside en su forma, en su más íntima esencia. Cabría preguntarse entonces por los elementos que la identifican, o que la hacen ser como es, y, al mismo tiempo, la diferencian del resto.

Decía Santo Tomas de Aquino que «la belleza incluye tres condiciones: integridad o perfección (integritas sive perfectio), ya que aquello que está dañado es por eso mismo feo; proporción adecuada o armonía (debita proportio sive consonantia); y por último, brillantez o claridad (clari-

2 Op. cit. p. 99.

3 Op. cit. p. 112.

4 Acerca de las inmerecidas visiones negativas de esta época es esclarecedor el libro publicado no hace mucho: Pemoud, R., Para acabar con la Edad Media, Barcelona, José J. Olañeta, editor. 1998, en el que, entre otras cosas, dice: «Si a un medievalista se le metiera en la cabeza componer una antología de disparates sobre el tema, la vida cotidiana le ofrecería materia más que suficiente». 
tas), ya que se llama bellas a las cosas cuyo color es brillantem, ${ }^{5}$ La asociación de belleza y claritas, que procede del platónico Pseudo-Dionisos (s. V) -y será incorporada también a la estética por san Buenaventura, san Alberto Magno y Ulrico de Estrasburgo-, será una referencia constante en nuestra reflexión.

\section{DE LOS CARACTERES QUE DEFINEN UNA OBRA}

Lo cierto es que un análisis detenido de las obras nos confirma que estos elementos están sujetos a distintas variables de la composición:

- Su finalidad: no tienen el mismo carácter las obras concebidas para la misa, como las destinadas al oficio divino, o para una procesión, o para otros ritos de que se compone el mundo litúrgico-musical del Medievo.

- Su espacio temporal: el sentido de expectación del tiempo de adviento es diferente, por ejemplo, del marcadamente penitencial de cuaresma o del gozo que aflora en la celebración de la pascua. El mismo contraste existe entre la triste celebración de unas exequias, o la esperanza que se abre en el bautismo, o el sentido de compromiso de una profesión monástica.

- Su destino: los cantos nacen, en su origen, para un experto solista, o para el grupo de especialistas que componen la schola, o para el conjunto de los asistentes a una celebración.

- Su estructura: muy diferente es, por ejemplo, el canto in directum del solista - sin alternancias ni interrupciones - del canto responsorial, donde se da un constante y fluido diálogo entre el solista y el coro, o el canto antifonal, en el que la pieza es interpretada a dos partes por todos los asistentes.

- Sus cualidades internas: tempo, ritmo, modalidad, de las que se hablará más adelante.

La interconexión de estos elementos, además de configurar musicalmente cada una de las piezas, obtendrá como resultado una estética distinta. A nadie se le escapa, en efecto, que «suena» de modo distinto una obra destinada a celebrar el nacimiento de un niño, que aquella otra que recoge el lamento por la pérdida de un ser querido. El compositor, si es que podemos hablar así en una música cuyos autores desconocemos, reflexiona sobre un texto, contempla el hecho en él descrito, y de su interiorización brota la música. Lo único que ha hecho, en definitiva, ha sido plasmar su vivencial reflexión estética en unos sonidos, que, por su parte, producirán unos efectos en función de la organización de aquellos elementos que los definen. ${ }^{6}$

Hay, por lo demás, otros importantes y misteriosos caracteres en la obra musical que van a condicionar su resultado estético final. Uno de ellos es la altura del sonido, altura producida por el número de vibraciones. Las vibraciones muy rápidas, por ejemplo, estimulan en gran medida el sistema nervioso, moviendo a la sensibilidad a la ardorosa agitación o a la bulliciosa alegría; las más lentas, por el contrario, inducen a la calma o a la relajación.

5 Summa theologica, 1.39. art. 8.

6 Vid., Alvin, J., Musicoterapia, Barcelona, Paidós, 1997 y Bonny, H., y Savary, L. La música y su mente. Cómo la misica puede transfonnamos imeriomente, Madrid, EdaffNueva Era, 1994. Que la música puede activar diferentes zonas del cerebro y que podría llegar a resolver problemas cerebrales, como la pérdida de memoria, son algunas de las conclusiones del Congreso de la Sociedad para la Neurociencia, celebrado en los Ángeles (EE.UU) en noviembre de 1998. 
Lo mismo acaece con los intervalos, o distancia entre dos sonidos. La organización de los intervalos puede ser agradable o desagradable al oído, produciendo un bienestar general o un creciente desasosiego.

En el terreno de la intensidad, es decir, de la amplitud de sus vibraciones, un volumen débil da la sensación de intimidad o de recogimiento, mientras que un volumen fuerte evoca la fuerza o el poderío.

¿Y qué decir del timbre? Se suele hablar del mismo como el «color» de la música —Darwin opinaba incluso que tenía raíces biológicas-, si bien lo que en realidad puede provocar es comunicación o distanciamiento entre el intérprete y el oyente.

En cuanto al ritmo, es quizá lo más evidente de la música. Un ritmo lento sugiere cierta atemporalidad, como si el tiempo se detuviera momentáneamente y nuestro deambular con él; un ritmo repetitivo, por su lado, puede ser deprimente o inductor de una especie de transporte o éxtasis.

En fin, todos estos elementos - manifestación de las experiencias del compositor- sirven para expresar sus emociones, gustos, y creencias; en definitiva, su reflexión sobre lo bello. Estas condiciones de la música, íntimamente ligadas a la literalidad de las obras, así como a sus modos de composición, ${ }^{7}$ favorecen nuestra percepción de lo bello en las obras musicales. Éste será nuestro objetivo, y asi será nuestra reflexión sobre lo bello en este tipo de música cristiana medieval.

No haremos, por tanto, un estudio histórico de esta estética; otros eminentes autores ${ }^{8}$ se han detenido en ello. Nosotros vamos a tratar de avizorar, sobre todo, las manifestaciones estéticas contenidas en estos repertorios, para rescatar la embriaguez, el estupor, la desolación y hasta la desmesura que habitan en sus entrañas.

Es, por tanto, un viaje iniciático al mundo de lo bello, a la delectación sonora, al fulgor transmitido por quienes sabían expresar sus pasiones más íntimas mediante el artificio sonoro. Un viaje que ora será sobrecogedor, ora lleno de serenidad, ora luminoso, ora dulce reposo. Porque es todo esto y mucho más lo que se oculta detrás de las melodías que, a lo largo de los siglos, han servido para calmar desdichas y desolaciones; para apaciguar extravíos y contiendas; para escanciar arrebatos y delectaciones; para, en fin, ensanchar el alma y espigar sus contradicciones.

Es, en verdad, la belleza que late en estos sentimientos hechos música lo que da sentido a nuestro viaje, lo que justifica nuestra prisa por transitar una vía milenaria, llena de colores y de sonidos, de abismos y de atajos, de tormento y de transfiguración. Porque la música no es otra cosa que la expresión alegre o dolorida de los sentimientos humanos. Y si en el alma humana cabe todo, en la música, que es su reflejo, todo tiene cabida. Con palabras llenas de poesía y belleza lo expresaba

7 Los modos son la esencia musical de cualquier composición gregoriana. Según la teoría del octoekos, hoy parcialmente superada por la de las wcuerdas madre», son 8 los modos musicales en el canto gregoriano. Desde la Edad Media se conocen como protus auténtico (modo I), tónica en re, dominante en la; protus plagal (modo II), tónica en re, dominante en fa; deuterus auténtico (modo III), tónica en mi, dominante en si; deuterus plagal (modo IV), tónica en mi, dominante la; tritus auténtico (modo V), tónica en fa, dominante en do; tritus plagal (modo VI), tónica en fa, dominante en la; tetrardus auténtico (modo VII), tónica en sol, dominante en re; tetrardus plagal (modo VIII), tónica en sol, dominante en do.

8 Vid. Fubini E. op. cit.; Tatarkiewicz, W., Historia de la estética. II. La estética medieval Akal / Arte y Estética. Madrid, 1989; Bruyne, E de, La estética de la Edad Media, Madrid, Visor, 1987, y Estudios de Estética Medieval, III vol. Madrid, Gredos, 1958-1959; Rowell, L., Introducción a la flosofia de la música. Barcelona, Gedisa, 1996. 
así un esteta y, al tiempo, especialista en Estética. «Música mística que nos lleva al otro lado de la razón, que glorifica el amor como vida y muerte, que dignifica la came en tanto que cmblema del espíritu, y concede a nuestros oídos el honor de ser puerta abierta al más allá, escuchando lo invisible, expresando lo inefable»?

En adelante, dejando sentado estos principios y con el apoyo de obras significativas del repertorio litúrgico-musical del Medievo, recorreremos los distintos jalones de este itinerario, para extraer de su análisis los resultados estéticos que identifican este rico tesoro musical. Habrá que entrar, para ello, en el corazón del autor, en su sensibilidad, en su estado de ánimo, en sus condicionantes, para, a través de todo ello, entender el mensaje y la estética subyacentes.

Evidentemente, esta reflexión sobre lo bello, esta contemplación del hecho musical, puede asomarse a tantas parcelas del conocimiento musical como variedades han existido a lo largo de los siglos, pues muchas son las manifestaciones musicales en la historia de la humanidad, y a lo largo y ancho del universo mundo. Por eso, antes de entrar a estudiar con detenimiento el fenómeno estético del canto litúrgico medieval, conviene definir, ya, a qué repertorio se alude $y$, obviamente, qué repertorios se excluyen del estudio.

\section{LA MÚSICA MEDIEVAL, DE ORIENTE A OCCIDENTE}

Es sabido que todas las formas de la música medieval cristiana tienen un mismo origen -las primeras comunidades de cristianos de Palestina-, y-que sus raíces últimas se encuentran en la sinagoga judía, de donde procedían los primeros conversos a la nueva religión, aparecida con Cristo. ${ }^{10}$ Con la difusión de esta nueva forma de vida va a extenderse, por Oriente y Occidente, el concepto de oración pública cantada. Con el paso del tiempo irán apareciendo las distintas formas musicales, que servirán a los cristianos para expresar sus sentimientos en cada uno de los momentos de la jornada litúrgica.

Esta jornada estaba jalonada, como sucede todavía hoy, alrededor de momentos intensos de oración comunitaria cantada, entre los que sobresalía la Misa. Encontramos así el monumental repertorio de la misa, contenido en magníficos códices, denominados Cantatorium - cantos del solista-, Graduale - cantos del propio de la misa-, Sacramentarium - oraciones del presidente de la asamblea-, Troparium - cantos del ordinario, generalmente tropados-, Lectionarium lecturas del Antiguo y del Nuevo Testamento-. Esta solemne celebración iba enmarcada por las distintas horas del Oficio Divino - Opus Dei-, que recorrían la jornada desde antes del amanecer hasta la puesta del sol: maitines, laudes, prima, tertia, sexta, nona, vísperas y completas."

En el mundo medieval, la primacía en esta oración cantada correspondía a la voz, porque los Padres de la Iglesia ${ }^{12}$ de los primeros siglos no apreciaban en demasía - $y$, en ocasiones, condena-

9 Zaldívar, A., En torno al misticismo sonoro. Música Sufi, en Música en la Aljaferia. Homenaje a Avempace. Aragón LCD Prames, Zaragoza, 1999, p. 67.

10 Vid. Gastoué, A., Les origines du chant romain, París. Picard \& Fils, 1907.

11 Vid. Salmon, P., Loffice divin au Moyen Age, Paris, Les Éditions du Cerf, 1967.

12 Vid. Gérold, Th., Les Pères de l'Église et la musique, Strasbourg, Emprimerie Alsacienne, 1931 (reeditado en Ginebra, Minkof Reprint, 1973). 
ban - la utilización de instrumentos musicales en la liturgia. San Clemente de Alejandría, ${ }^{13}$ por ejemplo, proclamaba: «Pero el que proviene de David y era antes que él, el Logos de Dios, ha despreciado la lira y la cítara, instrumentos sin alma (...) y canta a Dios con este instrumento polifónico que es el hombre». Habrán de pasar los siglos para que aparezcan otros testimonios, como el de Hildegarda de Bingen, ${ }^{14}$ quien dará una visión harto distinta: «Para que la gente se acordase de la dulzura de las alabanza divinas (...) los mismísimos santos profetas, instruidos por el espíritu que habían recibido, no sólo cantaban salmos y cánticos para encender la devoción de sus oyentes, sino que también crearon a tal efecto instrumentos de distintas clases con los que producir melodias variadas, para que, tanto por la forma y calidad de esos instrumentos, como por el sentido de las palabras que recitaban acompañándose de ellos, sus oyentes, adoctrinados y formados por elementos exteriores, aprendieran algo sobre su realidad interior».

En este mistérico mundo de la liturgia, sólo la voz es capaz de conmover, de expresar y transmitir mensajes. De aquí que quede fuera de nuestro viaje el rico mundo sonoro de los instrumentos, su estética y sus potencialidades, desarrolladas sobre todo a partir del Renacimiento. ${ }^{15}$

Tampoco cabe en nuestro itinerario la música bizantina, ${ }^{16}$ en vigor durante el imperio bizantino, desde el año 330 a de C. - fundación de la ciudad de Constantinopla- hasta la caída de esta ciudad en manos de los turcos y la derrota de Bizancio, en 1453; ni las prácticas musicales de las iglesias orientales no bizantinas: ritos sirio-antioquenos, ${ }^{17}$ sirio-jacobita y sirio-católico, ${ }^{18}$ rito maronita, ${ }^{19}$ asirio (nestoriano y caldeo), ${ }^{20}$ armenio, ${ }^{21}$ copto, ${ }^{22}$ y etiope. ${ }^{23}$ Aun reconociendo la importancia de sus ritos y de su música, y procediendo estas prácticas de una misma fuente, van a tener un desarrollo distinto; y muy pronto cada región va a celebrar la liturgia en su propia lengua. Muy diferente será la evolución en Occidente, donde, tras dos siglos de liturgia en griego, se adoptará definitivamente el latín como base para las composiciones literario-musicales.

Sabemos asimismo que, en el Medievo occidental, aun manteniendo la unidad del latín, aparecerán también repertorios distintos en las diferentes áreas geográficas: el canto hispano («mozá-

\section{Protept, 1, 5, 11-18.}

14 Hildegarda de Bingen (1098-1179) es una de las pocas mujeres compositoras conocidas de la época. Consagrada a la vida monástica desde niña, fue mística, consejera, teóloga, escritora, curandera y música. Últimamente se ha redescubierto su fascinante figura, y se están llevando a cabo diversas grabaciones de sus obraš. Vid, Epinet-Burgard, G., y Zum Brunn, E., Mujeres trovadoras de Dios. Una tradición silenciada de la Europa medieval, Barcelona, Paidós, 1998; y Dronke, P., Las escritoras de la Edad Media, Barcelona, Grijalbo Mondadori, 1995.

15 Un ejemplo, entre muchos, puede escucharse en el disco Gregoriano y Órgano en Aragón. Siglo XVII: la tradición de La Seo de Zaragoza. Schola Gregoriana Domus Aurea. Dir. Luis Prensa; Órgano: Jesús Gonzalo. SAGA, Madrid, 1998.

16 Monumenta Musicae Byzantinae, ed. Casten Höeg, H.J.W. Tyllyard y Egon Wellesz, Copenhague. Las relaciones entre esta música y el canto litúrgico occidental han sido objeto de estudio por expertos, aunque todavia queda mucho por desvelar.

17 Wrigh, W. Catalogue of siriac manuscripts in the British Museum, Londres, 1870-1872, y Zotenberg, H., Catalogues des manuscripts syriaques et sabéens (mansaittes) de la Bibliothèque nationale, París, 1874.

18 Jeannin, J., Mélodies liturgiques syriennes et chaldéennes, 2 vol., Paris- Beirut, 1924.

19 Hayek, M., Liturgie maronite. Histoire et textes eucharistiques, París, 1964.

20 Vadakel, M., Liturgical melodies of the Chaldaic Syrian Rite, India, Alwaye, 1954.

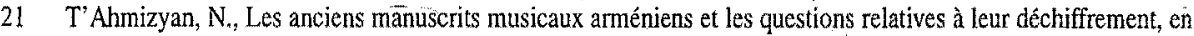
Revue des Etudes arméniennes, n.s. VII (1970), 267.

22 . Badet, L., Chants liturgiques des coptes, El Cairo, 1899.

23 Kebede, A., The music of Ethiopia: its development and cultural setting (tesis en la Wesleyan Uni., Connecticut, 1971). 
rabe»), ${ }^{24}$ en la península ibérica; el canto beneventano, en el sur de Italia; el canto romano, en la ciudad de Roma y su área de influencia; el canto milanés, en el norte de Italia; el canto galicano, en las Galias.

\section{ACERCA DEL CANTO GREGORIANO}

Sin embargo, el que a nosotros más nos interesa es el conocido como canto gregoriano, el más representativo en la Edad Media, desde el punto de vista de la calidad y de la cantidad, amén de haber sido el único, junto con el milanés, en haber sobrevivido a los avatares del tiempo y de la historia y haber llegado en uso hasta los umbrales del siglo XXI.

Conviene a nuestro propósito definir desde el principio qué se entiende por canto gregoriano, para, a continuación, tratar de desentrañar sus caracteres estéticos, seguramente aquellos que hicieron posible su pervivencia por encima de otras músicas coetáneas. El canto gregoriano es, pues, el repertorio litúrgico-musical de la Iglesia de Occidente, y se caracteriza porque es una música vocal y monódica. Vocal, porque el único instrumento utilizado es la voz humana, y monódica, porque excluye cualquier tipo de polifonía.

Hasta los legos en las artes musicales saben que este repertorio litúrgico musical del Medievo recibe su nombre del papa Gregorio Magno (590-604), a quien la leyenda atribuye su composición, atribución que científicamente hemos de descartar. En efecto, dos siglos y medio después de la muerte de Gregorio, un diácono de Roma, Juan de nombre, redacta su biografía, en la que dice: «En la casa del Señor, a imitación del otro sabio Salomón, y a causa de la compunción de la dulzura de la musica, el más celoso de los chantres recopiló con gran utilidad el antifonatio "centón"; constituyó también la Schola cantorum, que todavía canta en la santa iglesia romana según los mismos principios». ${ }^{25}$ Esto es, desde un punto de vista histórico, cuanto podemos atribuir al papa Gregorio: la recopilación de un antifonario y la creación de una escuela de cantores. Lo que no es poco.

Hay quien ha propuesto ${ }^{26}$ el nombre de «repertorio franco-romano» como el más ajustado a la realidad de este mundo musical del Medievo cristiano occidental. En efecto, en la segunda mitad del siglo VIII, el papa Esteban II acude a París en busca de la ayuda militar de Pipino el Breve, frente a la amenaza de los lombardos. El contacto del papa Esteban II y de sus cantores con la música que se interpretaba entonces en la liturgia de París hace que los romanos aprecien las diferencias entre ambas liturgias. Es a partir de este hecho cuando se produce lo que se ha venido en llamar «mestizaje» 0 «hibridación» de dos repertorios: repertorio romano y repertorio galicano. De la fusión de ambos nace el canto gregoriano. ${ }^{27}$

24 Rojo, C., y Prado, G., El canto mozárabe, Barcelona, Diputación Provincial, 1929; Fernández de la Cuesta, L., Historia de la música española, I, Madrid, Alianza Música, 19888; Zapke, S., El antifonario de San Juan de la Peña (s. X-XI). Estudio litúrgico-musical del rito hispano, Zaragoza, Institución «Fernando el Católico», 1995; y Ferrer, I.M., Curso de liturgia hispano-mozarabe, Toledo, 1995.

25 Vita S. Gregorii, I, II, c. VI.

26 Dom Jean Claire, monje de la Abbaye St. Pierre de Solesmes, maestro de coro, musicólogo e investigador.

27 Véase, al respecto, Bernard, Ph., Du Chant romain au chant grégorien, Paris, Les Éditions du Cerf, 1996; Hyley D., Westem plainchant, Oxford, Clarendon Press, 1995; Saulnier, D., Le chant grégorien, quelques jalons, Université Catholique de l'Ouest, 1995; y Calahorra, P., Historia de la música en Aragón (Siglos I-XVII), Zaragoza, Librería General, 1977. 
Habrá que esperar todavía un tiempo - hasta finales del siglo IX y comienzos del X-para que este mundo de ricas sonoridades haga el tránsito de la memoria oral al bello pergamino, y los sonidos adquieran por fin forma física y volumen. De las enormes ventajas que esta invención tendrá sobre el desarrollo de la música, de su expresión estética y de su facilidad para el aprendizaje da cuenta Guido de Arezzo (995-1050), en carta dirigida a un amigo: «El papa Juan, ${ }^{28}$ que se encuentra a la cabeza de la Iglesia romana, ha oído hablar de la reputación de nuestra escuela de canto. Se ha enterado de cómo, mediante los antifonarios, los jóvenes pueden aprender cantos que jamás habían escuchado anteriormente. Se quedó muy sorprendido y envió a tres mensajeros para que me llevaran ante él (...). El papa se puso muy contento al verme (...) y me hizo muchas preguntas. Ojeó las páginas del antifonario como si de un gran prodigio se tratara (...) No se movió de su silla hasta que hubo aprendido a cantar un versículo que jamás había escuchado. ¿Qué más decir? Yo me tuve que ir rápidamente de Roma, porque las fiebres veraniegas, en estos sitios húmedos y pantanosos, me sientan fatal. Sin embargo, quedamos en que volvería en invierno para explicar nuestro trabajo al papa y a su clero».

La aparición de la escritura musical será de crucial importancia no sólo para la perpetuación de melodías centenarias, transidas de honda belleza, sino para el florecimiento y desarrollo de otro mundo estético: el de los códices miniados, ricamente iluminados. ${ }^{29} \mathrm{La}$ belleza sonora irá acompañada en adelante de ricos ornamentos visuales, que completarán su incorpóreo mensaje musical.

\section{DE LA HISTORIA A LA ESTÉTICA}

Llegados a este punto de nuestro viaje, y delimitado el objeto de nuestro recorrido, conviene recordar las palabras de Dom Ferretti ${ }^{30}$ acerca del tema que nos ocupa: «La estética musical es la ciencia o la filosofía de lo bello aplicado al arte de los sonidos. Como justamente observa Riemann, ${ }^{31}$ ésta se propone favorecer y desarrollar no la habilidad técnica, sino la inteligencia y la comprensión de la obra artística en sí misma». Y más adelante: «Algunos autores prefieren denominar a esta ciencia como Teoría de las formas musicales, en lugar de Estética musical. Y esto se justifica porque hay tantas obras nacidas del ingenio del hombre como seres naturales y vivos: es la forma la que constituye su mismo ser; es la fuente primera de todas las propiedades y cualidades de lo bello objetivamente considerado».

Nuestro itinerario, en efecto, recorrerá las formas musicales gregorianas como si de una especie de cartografía estética se tratara, sin olvidar que estas formas derivan de las formas litúrgicas y que una determinada obra ha sido concebida para un uso concreto, para un momento preciso de la liturgia. Esta íntima imbricación condicionará toda percepción estética de cualquier obra monódica medieval, porque cada forma nace para un intérprete concreto y en un estilo determinado. Dicho lo cual, preciso es detenernos ya en la primera etapa de nuestro viaje.

28 Se refiere a Juan XIX, que fue papa de 1024 a 1033.

29 Una muestra significativa, entre otras muchas, puede encontrarse en Falcón Pérez, M. Pilar, Estudio artístico de los manuscritos iluminados de la Catedral de Tarazona. Análisis y catalogación, Zaragoza, Gobierno de Aragón, 1995.

30 Ferretti, P., Esthétique grégorienne ou traité des formes musicales du chant grégorien, Solesmes, 1938, p. VII.

31 Les éléments de l'Esthétique musicale, París, ed. Felix Alcan., 1906. 


\section{ACERCA DEL REPERTORIO DEL SOLISTA}

Dentro de las piezas que configuran el vasto panorama de la misa, empezamos nuestro recorrido por el repertorio del solista, para pasar más adelante al de la Schola, y al del Coro. Llamado en sus orígenes salmista, el solista tenía como principal cometido la recitación de los salmos, por lo general en un estilo silábico: es la forma de recitativo, la de mayor sobriedad en su decurso sonoro. Aquí, la monodía se transforma en insistente monólogo; un monólogo ofrecido al solista que recita, declama. Es una especie de síntesis entre hablar y cantar; no busca adornar el texto, sino darle un mayor brillo y realce. Su extrema sobriedad es un paradigma de la belleza. Y ello porque contiene toda la mesura posible: nada le sobra, nada le falta. Sus recursos musicales son mínimos, a modo de ráfagas, que ora acentúan una palabra, ora puntúan el texto con precisión y serena belle$\mathrm{za}$, ora quiebran el discurso como fuego que se desvanece. Véase, si no, esta lectio ${ }^{32}$ del oficio de maitines del día de Navidad, texto musicado del profeta Isaías:

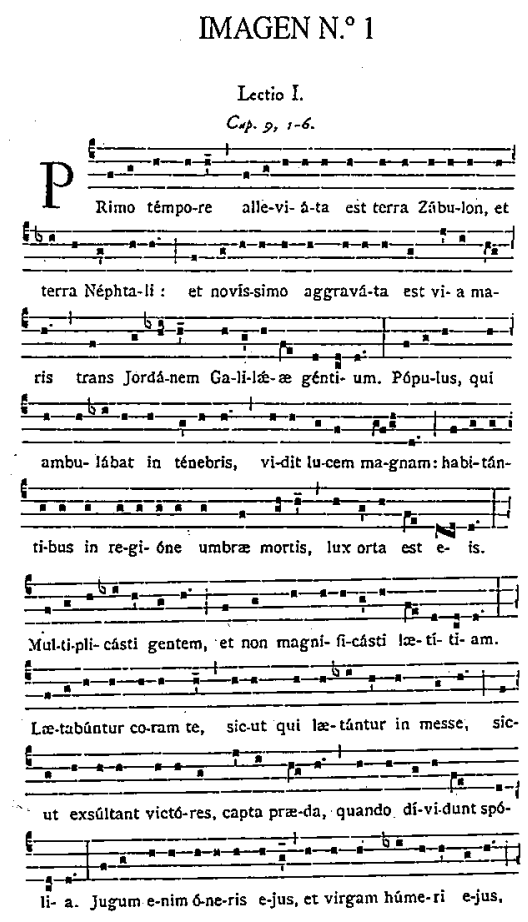

El pueblo que andaba a oscuras, vio una luz intensa. Sobre los que vivian en tierra de sombra brilló una luz. Acrecentaste el gozo, hiciste grande la alegría. Se han alegrado al verte, como se alegran en la siega, como se gozan repartiendo el botin. ${ }^{33}$

32 Edición de In nocte nativitatis Domini, París, Desclée et Socii, 1936, p. 86. Puede escucharse una bellísima grabación en Exsultemus. La joie chrètienne. Choeur des moniales de l'abbaye de St. Michel de Kergonan. Dir. Dom 0. Bossard. Art et musique.

33 Is. 9, 1-6. Traducción de la Biblia de Jerusalén, Bilbao, Desclée de Brouwer, 1966, p. 1009. 
Esta sobria mesura en el canto explica la contestación que, en cierta ocasión, dio Dom Jean Claire, maestro de coro de Solesmes, cuando le preguntaron qué piezas prefería del repertorio gregoriano: «En la iglesia abacial de Solesmes, consagrada en 1010, todos los días se han cantado, con las mismas melodías, oraciones, el pater, el prefacio; todos los días desde hace casi 1000 años, y nadie se ha cansado, nadie ha pedido cambiarlo... Ahí está, en mi opinión, el criterio del arte, la señal de la obra de arte que desafía a los siglos. Yo diría que prefiero lo sustancial a los accidentes, lo esencial a lo accesorio, la línea a la ornamentación, y elijo los grandes recitativos tradicionales de la misa y del oficio, el canto sobrio y puro de las oraciones, del Pater, de las lecturas... Sólo estos verifican plenamente el antiguo dicho: "Caput artis decere", la cumbre del arte es la perfecta conveniencia de los medios al fin. Porque, aquí, esta conveniencia no es ya más o menos relativa sino vecina de lo abśoluto, no excepcional sino habitual, no superficial sino profunda e intima.

\begin{abstract}
«Daría toda mi obra por la gloria de haber compuesto la melodía del prefacio». Al escribir esto, Mozart parece haber entendido que hay dos clases de música, muy diferentes entre sí. Está la música de un hombre, de un estilo, de una época, la música de una sensibilidad, de una cultura, que gusta al siglo en el que aparece porque corresponde al gusto contemporáneo, pero que, en la época siguiente será irremediablemente superada, cuando no sobrepasada. Y está, por otro lado, la música que nada o poco debe a una época, a un estilo, a una sensibilidad, la música que no se conforma a un modo determinado, y por ello sobrevive a todas. $^{34}$
\end{abstract}

Pero el solista no se contentará con esa expresión queda, rayana a un silencio sonoro; no. En su labor creadora, avanzará en nuevas formas de expresividad musical hasta lograr mundos sonoros de contrastante complejidad: los Tractos y Graduales, del repertorio de la misa, y los versículos de los Responsorios prolijos del oficio divino. Unos y otros son formas conocidas como responsoriales, porque siguen a una lectura, bien sea en la Misa - Tracto y Gradual-o en el Oficio -Responsorios-. Ambas constituyen una respuesta a la lectura proclamada.

El tracto del Viernes Santo es un magistral ejemplo de esta evolución: desde el sobrio recitado al complejo mundo del artificio expresivo. Como se ha dicho, es el tracto - la capa más arcaica de los cantos de la misa - una forma interleccional, una respuesta a la lectura en forma de reflexión cantada. El solista medita sobre el salmo, y su reflexión adquiere la forma de canto. Sin las ataduras de un canto coral, puesto que canta solo, podrá detenerse allí donde más cómodo se siente, donde más vibra su sensibilidad, donde más consuelo encuentra. Y de este modo su improvisación seguirá solamente los dictados de su corazón. 


\section{IMAGEN N. ${ }^{\circ} 2$}
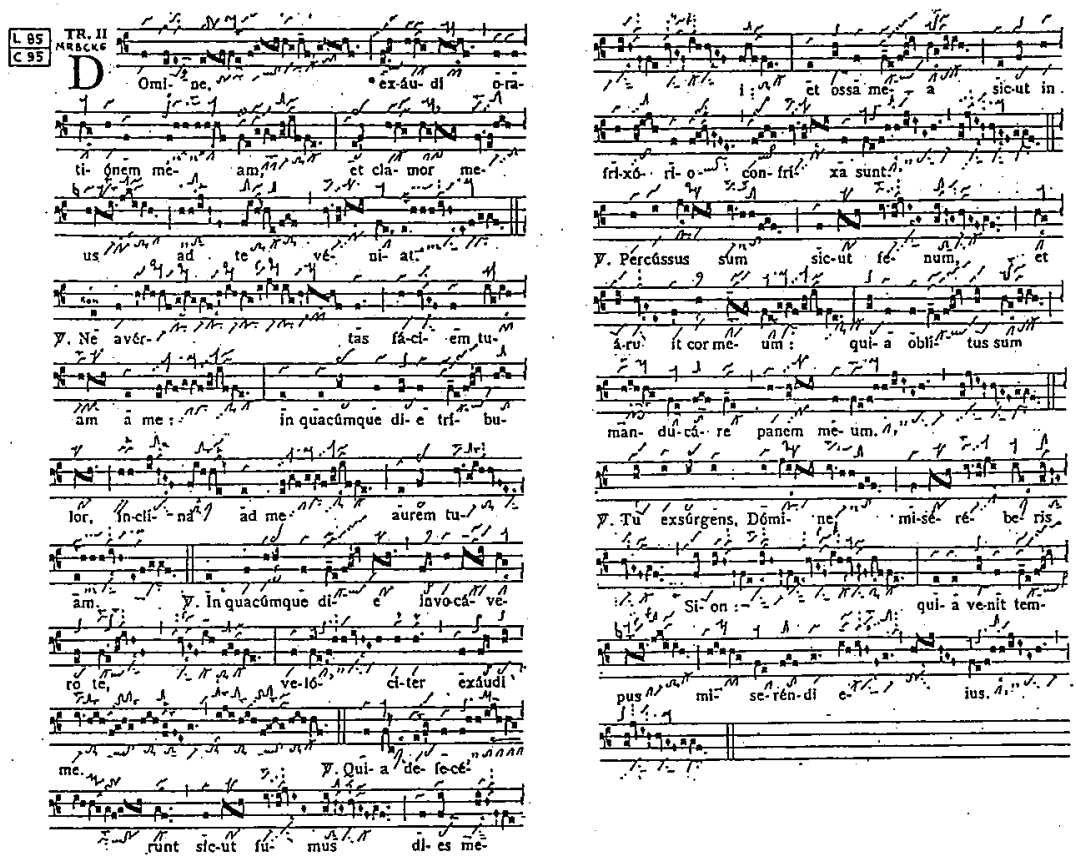

Señor, escucha mi oración, que mi grito llegue hasta ti;

No ocultes lejos de mi tu rostro, el día de mi angustia;

Tiende hacia mi tu oído, el día en que te invoco, presto, respóndeme;

Pues mis dias en humo se disipan,

Mis huesos arden lo mismo que un brasero;

Trillado como el heno, mi corazón se seca,

$Y$ me olvido de comer mi pan;

Tú te levantarás, Señor, compadecido de Sión,

Pues ya es tiempo de apiadarte de ella. ${ }^{35}$

Su texto nos sitúa, desde el principio, en la estética del dolor, en el mundo de la desazón y del estupor, en la realidad abrasadora y amarga. Para lograr esta atmósfera doliente, el compositor echa mano de los recursos musicales del modo II, denominado por los antiguos «tristis». La estremecida insistencia en el grave y la huida de los sonidos más agudos confieren a este tracto un ambiente de inconsolable infortunio, excepto en su último versículo, donde la melodía se yergue para hallar el consuelo tenazmente buscado desde el principio de la pieza.

35 Graduale Triplex (en adelante GT), Solesmes, MCMLXXIX, p. 173. Sal. 101, 4-6. Puede escucharse esta obra en Cantemus Domino. La psalmodie du soliste dans la messe. Nova Schola Gregoriana. Dir. Alberto Turco. Arion, 1989. 
En efecto, ¡qué cruda desnudez, qué devastador sufrimiento el que se desprende de esta obra! La melodía intensifica el dramatismo del texto, y, merced a ella, el cantor parece ir a la deriva, tal es su soledad, tan desmesurado su dolor. El profeta Isaías sabe expresarlo como nadie cuando escribe: «...Como muchos se espantaron de él, porque desfigurado no parecía hombre, ni tenía aspecto humano.... Creció en su presencia como un brote, como raíz en tierra árida, sin figura, sin belleza. Lo vimos sin aspecto atrayente, despreciado y evitado por los hombres, como un varón de dolores, acostumbrado a sufrimientos, ante el cual se ocultan los rostros, despreciado y desestimado» ${ }^{36}$ Con breves y hermosas palabras así lo expresaba un autor de nuestro tiempo:

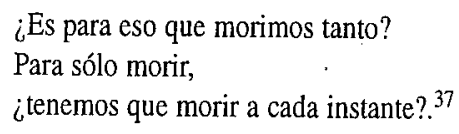

Estos sentimientos, en definitiva, no son otra cosa que el reflejo sonoro del mundo del compositor, de una amarga experiencia. Y así, de este modo, algo tan incorpóreo como el espíritu se materializa, se hace carne, se hace música; pasa, finalmente, del mundo inmaterial al material.

En este repertorio, el solista es el único intérprete, el único que canta y escenifica la parte del «drama litúrgico» que a él le corresponde. Su acción es seguida por los asistentes, que participan desde el silencio. Es, por tanto, en la expresión de su voz donde éstos se reconocen; y es en el arte de su rostro donde se manifiestan sus sentimientos. Parafraseando al abate Dinouart ${ }^{38}$ podríamos decir que es el rostro del cantor lo que más observa el oyente en la acción. En él juegan su papel todas las pasiones: es universal, pertenece a cualquier país y a cualquier lengua. Los más ignorantes saben leerlo, y reconocen en él la devoción, la disipación, la alegría, la tristeza, la cólera, la compasión. Por eso, debe ajustarse al tema, y permitir sentir o adivinar los movimientos del alma.

Triste sería nuestro viaje iniciático si se detuviera en este punto, en la expresión estética del sufrimiento, en el costumario del dolor. No; nuestro caminar nos depara otras sorpresas, porque el horizonte se ensancha a medida que avanza el compositor en sus experiencias interiores, en sus emociones y sentimientos, y en su búsqueda de expresarlas a través de la música. de Pascua?

¿Cómo, si no, entender el grito de júbilo que brota, hasta la desmesura, en el alleluia ${ }^{39}$ del día de Pascua?

\footnotetext{
36 Is. 52, 14. 53, 1-3.

37 De César Vallejo, citado por Carlos Gurméndez, La melancolía, Madrid, Colec. Austral, Espasa Calpe, 1994, p. 130.

38 Abate Dinouart, El arte de callar, Madrid, Biblioteca de Ensayo Siruela, 1999, p. 30. Esta obra se publicó por vez primera en 1771 en París.

39 GT. pp. 197-198. Esta pieza ha sido objeto de múltiples grabaciones en todos los tiempos. Puede encontrarse, entre otros, en Paquês. Choeur des moines de l'abbaye Saint-Pierre de Solesmes. Dir. Jean Claire. Studio SM, París, 1986.
} 


\section{MAGEN N. ${ }^{\circ} 3$}

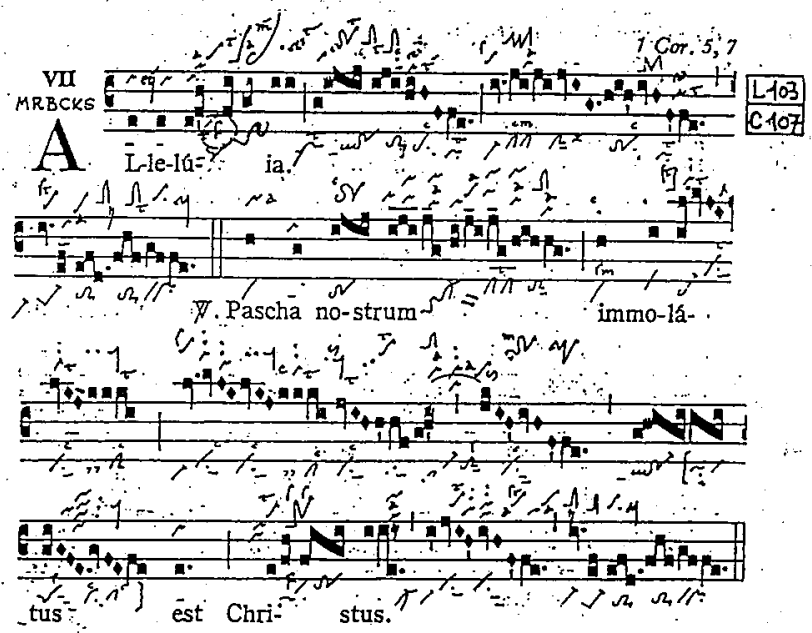

Alleluia. Cristo, nuestra pascua, ha sido inmolado, alleluia.

Hay en esta obra un mundo estético absolutamente distinto de cuanto acabamos de ver. Es el canto a la vida; una vida donde no existe el sufrimiento, ni el dolor. Aquí, el solista, tras hacer partícipe al coro en el canto de la palabra alleluia, se lanza hacia el agudo, como si quisiera traspasar todas las fronteras imaginables, como si pretendiera prescindir de lo material y, con su canto, entrar en un mundo lábil y completamente ajeno a las penumbras de la tierra. Es tal la luminosidad de su magnífico melisma que parece conducirnos a la ceguera; tal es su destello que parece abrasar todo en su decurso.

A diferencia del modo II de la pieza anterior, el músico hace ofrenda aquí de su gozo en un modo VII, «angelicus» para los medievales. Es su carácter más visible y llamativo la transparencia, el fulgor, la luminosidad. Su máxima expresión estética se halla en el agudo, lejos de las zonas sombrías del grave. De aquí procede su brillo cegador, así como de sus prolongadas e insistentes vocalizaciones sobre $a$, sobre $u-$ son los conocidos melismas o jubilus--, de los que san Agustín afirmaba: «¿Qué es jubilar? No poder expresar la propia alegría mediante palabras y, sin embargo, testimoniar con la voz lo que se experimenta dentro de uno mismo. Esto es lo que se llama jubilar. Obsérvese a quienes jubilan con unas cantilenas cualquiera y se dejan llevar a una alegría profana; a estos, mientras interpretan los cantos con palabras, se les ve exultar con una alegría que la lengua es incapaz de traducir, y jubilar para que la voz exprese los movimientos del alma, que no puede expresar con palabras lo que siente el corazón. Si estos jubilan, arrastrados por una alegría terrenal, ¿no debemos nosotros manifestar mediante el jubilus esta alegría celestial, que no podemos expresar con palabras?». ${ }^{40}$ 


\section{DEL REPERTORIO DE LA SCHOLA}

Seguimos nuestro caminar en busca de nuevas expresiones estéticas en la música del Medievo cristiano, y nos topamos con un repertorio pensado no ya para una sola persona, sino para un grupo de expertos cantores, a los que se les presupone también una gran destreza en las artes musicales. Es el conocido repertorio de la Schola, para la que, en su origen, se había creado la mayor parte de las piezas: los cantos procesionales del introito, ofertorio y comunión. Otros sentimientos, otra estética, otra expresión va a desplegarse ante nuestros ojos y ante nuestros sentidos.

Abrimos la primera puerta de este nuevo santuario y escuchamos el enigmático y misterioso mensaje:41

\section{IMAGEN N. ${ }^{\circ} 4$}
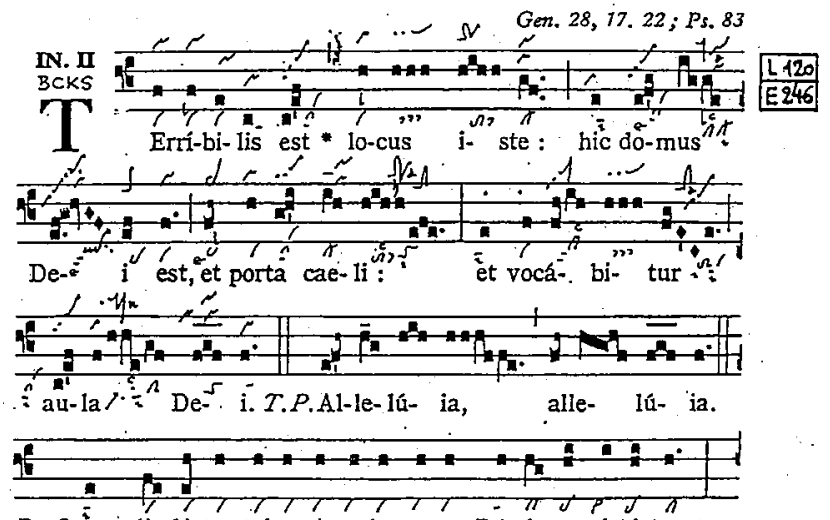

Ps. Quàm di- lécta taberná-cu-la to-a, Dómi-ne virtú-tum!
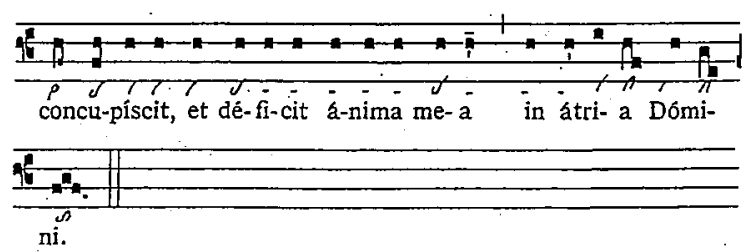

Qué terrible es este lugar: es nada menos que la morada de Dios y la puerta del cielo. Y se llamará morada de Dios. iQué delicia es tu morada, Señor de los ejércitos! Mi alma se consume anhelando los atrios del Señor: ${ }^{42}$

¿De qué manera expresar semejante mensaje? ¿De qué recursos estéticos echar mano para describir lo inconmensurable? ¿Adónde acudir para hallar una expresión musical apropiada? Para el músico medieval, la clave se encuentra en el texto, en las palabras que Jacob pronuncia después de haber teni-

41 GT. p. 397.

42 Gén., 28, 17.22; Sal. 83. Puede escucharse esta pieza en L'Epiphanie-La Dédicace. Choeur des moines de l'abbaye Saint-Pierre de Solesmes. Dir. Dom Joseph Gajard. IPG, París. 
do la visión de la escala que toca el cielo. Por eso, se recoge en su interior, y allí, en lo más profundo de su ser, resuena una melodía que inicia su caminar bajando una cuarta, como si en su descenso sonoro bajara de la escala de Jacob, o se internara en las entrañas de esa morada divina. Se ha hablado más arriba del modo II. Aquí volvemos a toparnos con él, pero con una estética distinta. Quizá sea ésta la característica más llamativa de los modos gregorianos, su capacidad para mutar, adaptarse y crear atmósferas y estéticas diferentes en función del texto. Decía Jeanneteau ${ }^{43}$ que, en gregoriano, más que hablar de 8 modos habría que atribuir a cada una de las piezas su propio modo. Por eso, más que la música «triste» de que hablaban los medievales, es aquí una música grave; llena de temor reverencial, quieta, callada. ¿Cómo no acordarse en este punto de un místico y poeta español, san Juan de la Cruz, en su maravilloso y transfigurado Cántico? «Y llama a esta música "callada" porque, como habemos dicho, es inteligencia sosegada y quieta, sin ruido de voces; y así se goza en ella la suavidad de la música y la quietud del silencio. Y así dice que su Amado es esta "música callada", porque en él se conoce y gusta esta armonía de música espiritual; y no sólo eso sino que también es la soledad sonora»."

Sentimientos y estética diferentes aparecen en Sederunt principes ${ }^{45}$, responsorio gradual de la fiesta del protomártir san Esteban. Esta forma musical aparece como tal en los siglos V-VI, fruto del trabajo de elaboración de la schola. Se trata, en realidad, de una adaptación del antiguo salmo responsorial, que se ve reducido en cuanto al texto, y enriquecido en sus melodías.

\section{IMAGEN N. ${ }^{\circ} 5$}

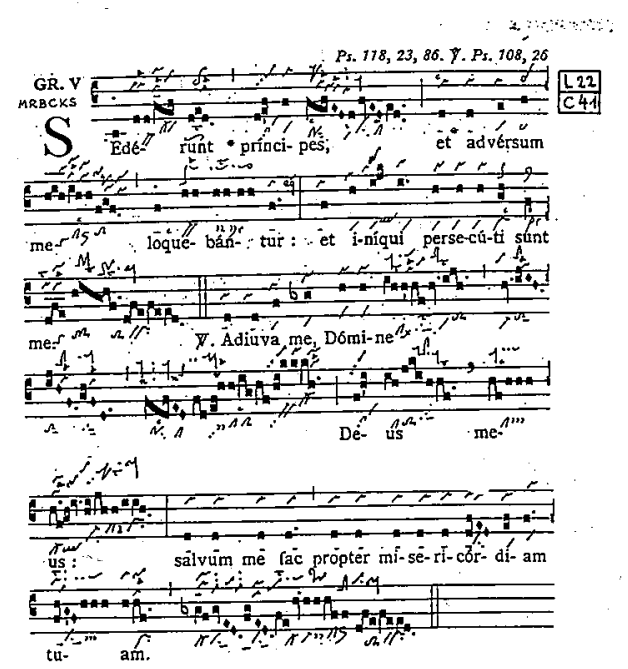

Los nobles se sientan a murmurar contra mi, y los insolentes me persiguen. Ayúdame, Señor, Dios mío, sálvame por tu misericordia.

43 Jeanneteau, J., Los modos gregorianos, Abadía de Silos, 1985.

44 San Juan de la Cruz, Cántico. Ed. de Simeón de la Sagrada Familia, Burgos, El Monte Carmelo, 1972, p. 272.

45 GT. p. 633; Sal. 118, 23, 86. 108, 26. Esta pieza puede escucharse en Vous serez mes témoins. Choeur des moniales de l'abbaye Saint-Michel de Kergonan (Francia). Dir. J. Jeanneteau. Art et musique. 
Se narra aquí la historia de Esteban, condenado a muerte y lapidado, según recoge el libro de los Hechos de los Apóstoles. Si el texto expresa con sobriedad un trágico acontecimiento, cual es la condena a muerte de Esteban, Ia música va a subrayar hasta el delirio el grito de auxilio que éste dirige a Dios: «Adiuva me, Domine». El progresivo ascenso de la melodía, desde el fa grave al fa agudo, expresa de manera admirable la dolorosa confianza de quien sabe que, tras su inmediata muerte, será acogido por aquel en quien cree, y la febril fascinación de quien todo lo juega a la sola carta de una demanda. Esa obstinada insistencia, esa pavorosa conciencia de la cercanía de la muerte surge desde lo más profundo de la obra musical —en el registro más grave del modo $\mathrm{V}$ - para, como sobrecogedor sollozo, ir ganando en intensidad y alzarse hacia el agudo más desolado donde volcar toda su angustia y esperanza: dos sentimientos contradictorios, que suenan aquí íntimamente ligados en la expresión musical. Es, podriamos aseverar, lo más cercano al éxtasis que no hace mucho expresaba así un pensador ya citado: «Misticismo que exalta el exceso de la embriaguez, jugando con lo extraño de un comportamiento aparentemente reprochable que es, en realidad, entrega total a lo divino, su correspondiente sonoridad debe expresar con plenitud la paradójica condición placentero doliente, de agitada inmovilidad en un quieto giro permanente propio del éxtasis». ${ }^{46}$

Quien tiene el inmenso privilegio de poder unirse en el canto al creador de esta obra maestra, experimenta en su interior la progresiva transformación que se va produciendo conforme avanza el canto. Esa experiencia, cercana al éxtasis, es — creemos - la manifestación más estremecida de la belleza en el mundo sonoro.

\section{DEL REPERTORIO DEL CORO}

¡Cuán distintas son las sonoridades que se escuchan tras la puerta que vamos a atravesar, qué diferente el mensaje, qué distinta su estética!

\section{IMAGEN N. ${ }^{\circ} 6$}

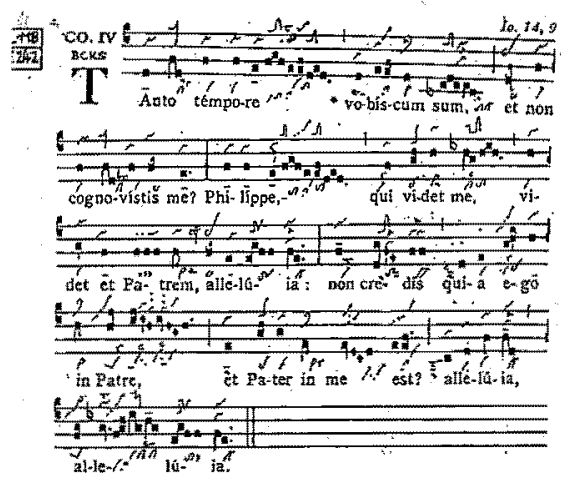

Con tanto tiempo que llevo con vosotros, ¿todavía no me conoces, Felipe? Quien me ve a mi está viendo al Padre. ¿No crees que yo estoy con el Padre y el Padre conmigo? ${ }^{47}$ 
Esta antífona de comunión -forma musical, que en los primeros siglos era invariable en texto y melodía - va a verse modificada también por la acción de la schola, con nuevos textos - de los salmos y del Nuevo Testamento- y nuevas melodías, utilizando por lo demás un estilo semi-adornado, que alterna con la recitación de un salmo a cargo del solista.

Estamos aquí ante un reproche, lleno de ternura, al amigo que lo ignora después de tanto tiempo de amistad. El músico - la melodía - pone en boca de Jesús una expresión cargada de nostalgia y de dulzura en el reproche tanto tempore, pero llena de firmeza y determinación en in Patre. Ese modo musical, conocido como deuterus plagal o IV, fue definido por Dom Gajard, magnífico maestro de coro de la Abadía de Solesmes, como «el modo que no acaba», tal es la sensación de nostalgia que deja al finalizar. Si pudiéramos atribuirle caracteres humanos, diríamos que es un modo «contemplativo», que «mueve a llanto y alegría, a ira y mansedumbre, a apacibilidad y terribilidad, a blandura y fortaleza». ${ }^{48}$

A riesgo de que se nos tache de hereje o iconoclasta, no podemos dejar de recordar las palabras que, en otro contexto y en un ambiente absolutamente distinto, escribió un autor de nuestros días: «Ser triste o melancólico protege contra los peligros y amenazas del mundo: el triste se sabe defender de los dolores que pueden conturbarle y hasta destruirle; el melancólico convierte en dulcedumbre la amargura de su tristeza... Voluntariamente nos hacemos tristes o melancólicos para poder contemplar con escepticismo distanciado los amargos y trágicos episodios de la historia del mundo ${ }^{49}$ Los sentimientos humanos - creemos- son tan parecidos entre las gentes, independientemente de las creencias y religiones, que a veces se vislumbran los destellos de la verdad en quien jamás ha pensado ser dueño de la misma.

Es precisamente ésta la reflexión estética que se deriva de la obra. ¿Ácaso no es el estupor lo que se adueña de quien no se ve reconocido por aquel a quien ama? ¿No es quizá una decepción mansa lo que se vislumbra tras cada una de las notas de esta antífona de comunión? Y de qué manera más admirable se ve transfigurado, aquí, un sentimiento de dolor en una obra musical de exquisita belleza.

La inseguridad y el miedo ante lo desconocido que, como acabamos de ver, el músico ponía en boca de Esteban se transforman ahora en firmeza en esta otra antífona de comunión Dicite: pusillanimes. ${ }^{50}$

48 Fray Pablo Nassare, Escuela misica, Zaragoza, 1724, cap. XVIII del libro I de la Primera Patte.

49 Guméndez, C. La melancolia, Colección Austral, Madrid, Espasa Calpe, 1994, p. 31.

50 GT. p. $23 ; 1 \mathrm{~s} .35 .4$. 


\section{IMAGEN N. 7}

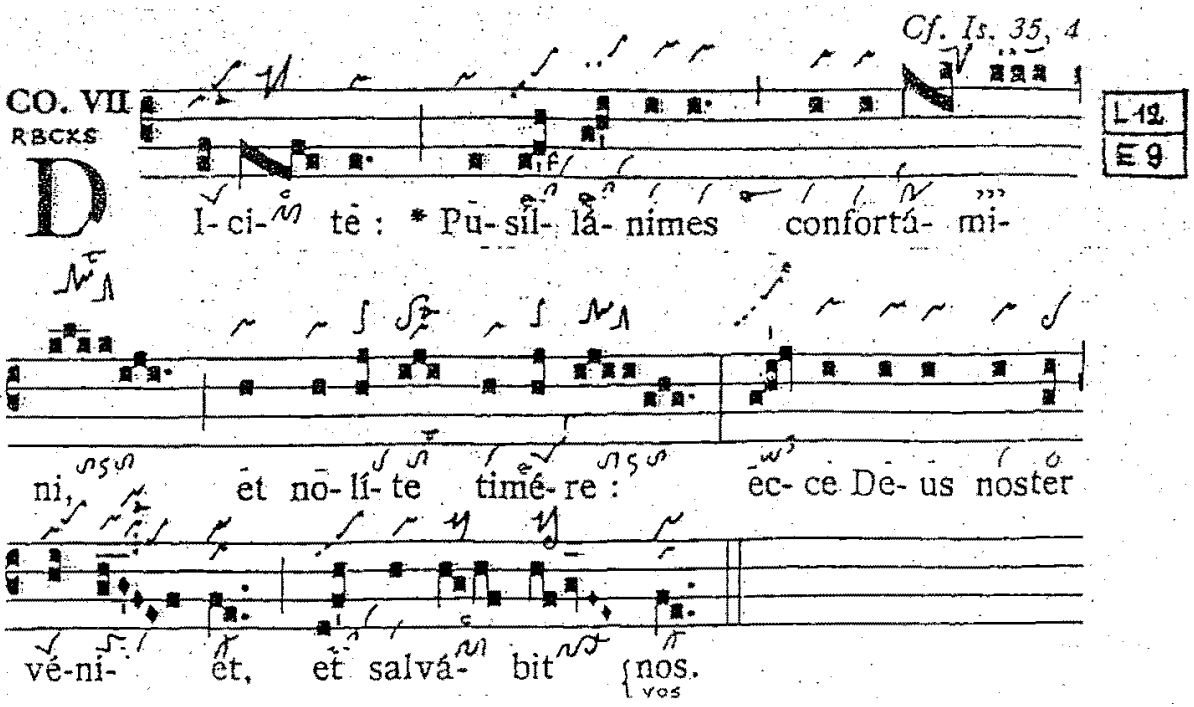

Decid a los de corazón intranquilo: iñimo, no tenáis! Mirad que nuestro Dios viene a salvamos.

La melodía canta en un modo VII, denominado - como ya se ha dicho- por los antiguos angelicus, angelical por su transparencia, por su altura, por sus fascinantes e impetuosas escapadas hacia el agudo. Es precisamente desde allí arriba, lejos de los efímeros extravíos del alma humana, desde donde puede el compositor expresar el grito de confortamini (jánimo!). El vértigo de la altura hace más visible el contorno en el que se mueven las inseguridades y los miedos humanos; desde esa evanescente atalaya, todo el paisaje interior se convierte en briznas luminosas que reconducen a su exigua proporción los avatares más inquietantes. Confortamini et noli timere se convierten así en la firme expresión musical de una sosegadora realidad. Lejos de la intranquilidad y el desasosiego provocados por los afanes del mundo, resuena también la voz de Luis Cernuda: «Frente a la turbamulta que se precipita a recoger los dones del mundo - ventajas, fortuna, posición-, me quedé siempre a un lado, no para esperar a que acabaran, porque sé que nunca acaban o, si acaban, que nada dejan, sino por respeto a la dignidad del hombre y por necesidad de mantenerla». El estímulo que la música ofrece para superar el desasosiego conduce finalmente a la sabia indiferencia ante la realidad.

¿Hay acaso algo más expresivo que las lágrimas para expresar el valor de la amistad? Eso es lo que aparece reflejado en la siguiente antífona de comunión, Videns Dominus. ${ }^{51}$

51 GT. p. 124; In.11,33.35. 43.44. 39. Puede escucharse, y verse, en el vídeo Tropos - Secuencias-Teatro litúrgico medieval, a cargo de la Schola Gregoriana Domus Aurea, con la dirección de Luis Prensa, publicado por la Institución «Fernando el Catolico» (Excma. Diputación de Zaragoza), y realizado por CPA, Zaragoza, 1097. 


\section{IMAGEN N ${ }^{\circ} 8$}

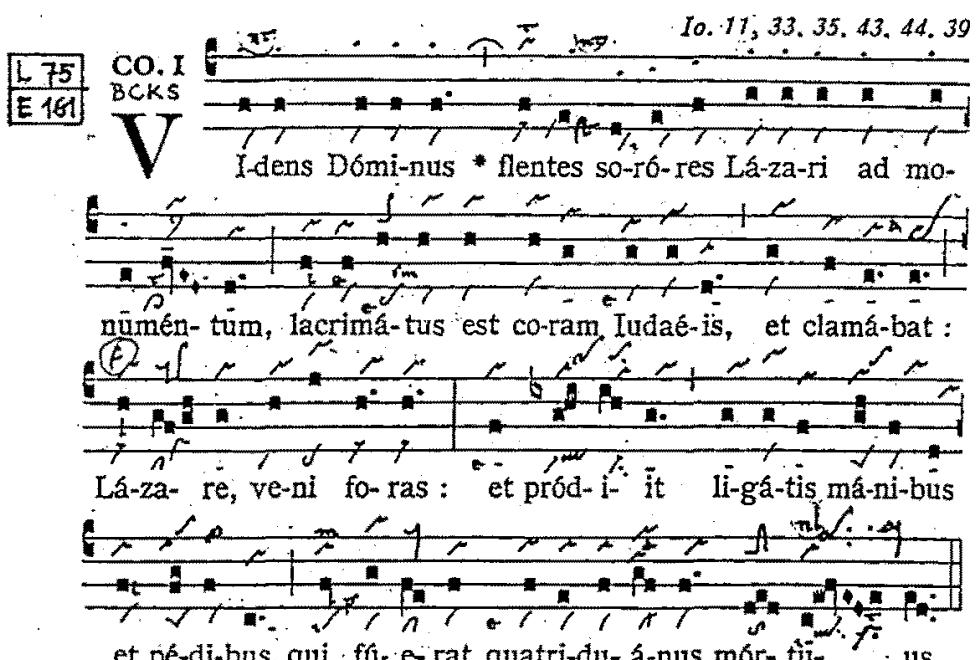

et pé-di-bus, qui $\cdot$ fá-e-rat quatri-du- á-nus mór-tü- ? . us.

Al ver llorar Jesús a las hermanas de Lázaro ante la tumba, se puso a llorar ante los judíos, y dijo: Lázaro, sal fuera. Y aquel que llevaba cuatro dias muerto, salió con las manos y pies enuteltos en el sudario.

Para entender la sobria expresión de esta pieza, en un modo I, y el imperativo grito de Jesús «Lazare, veni foras»- hemos de recordar el hecho acaecido. Lázaro, amigo de Jesús, muere, y cuando éste acude, ya lleva cuatro días enterrado. Las lágrimas asoman a sus ojos, y de su garganta sale el grito que devolverá a Lázaro a la vida. Musicalmente hay una tensión progresiva: comienza con un sereno recitado sobre fa, para pasar a continuación a sol y elevarse a la cuerda de la sobre la que narrar el llanto de Jesús. Viene luego el grito de Jesús, que se lanza desde el la hasta el do - la parte más aguda y lírica de la pieza - para ir en descenso a los niveles del inicio. Esta tensión musical sigue al pie de la letra al mundo estético de los sentimientos. Lejos de los trenos jeremíacos, al llanto manso le conviene una expresión queda; al grito vigoroso, una expresión firme y potente.

Si hasta aquí nuestro viaje ha discurrido a lo largo de las formas musicales que aparecen el repertorio de la misa, entramos ahora en el oficio divino con la antífona Montes Gelboé. La antífona sirve para introducir y concluir el canto de un salmo o de un cántico (Magnificat, benedictus). Entre el considerable número de 4000 , consideradas auténticas, aparecen de las más diversas épocas: desde las más arcaicas a las de composición más reciente. Las más antiguas suelen ser «melodías-tipo», que saben adaptarse a los textos más variados; otras proceden de la centonización, forma de composición a imagen de un mosaico; y las más tardías, de nueva invención y sin dependencias musicales de ningún tipo. Un magistral ejemplo lo encontramos en esta antífona para el Magnificat. ${ }^{52}$

52 Antiphonale Monasticum (en adelante AM), París-Toumai-Roma, Desclée et Socii, 1934, pp. 576-577; II S., 1, 21.25. 23. 


\section{IMAGEN N. ${ }^{\circ} 9$}

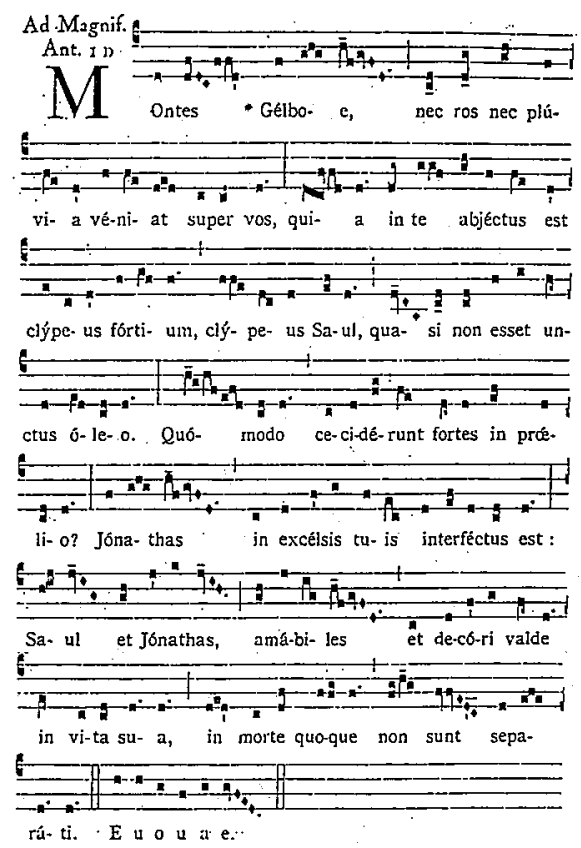

¡Montes de Gelboé, altas mesetas, ni rocío ni lluvia caigan sobre vosotros! Que allí quedó manchado el escudo de los valientes, escudo de Saúl, no untado con aceite. ¡Cómo cayeron los valientes en el combate!, Jonatán, herido en las alturas. Saúl y Jonatán, amables y llenos de gracia en vida, ni siquiera la muerte los pudo separar.

Esta bella antífona, de composición tardía, vuelve a tratar el tema de la amistad, en este caso entre David y Jonatán. Dice el libro I de Samuel que «cuando David acabó de hablar con Saúl, ${ }^{53}$ Jonatán se encariñó con David; lo quiso como a sí mismo (...) Jonatán y David hicieron un pácto, porque Jonatán lo quería como a sí mismo». ${ }^{54} \mathrm{Y}$ cuando Jonatán cayó abatido, David entonó esta elegía: «Cómo sufro por ti, Jonatán, hermano mío! ¡Ay, cómo te quería! Tu amor era para mí más maravilloso que el amor de las mujeres» ${ }^{55}$. Esta amistad —que sirvió de inspiración tanto para la composición de innumerables responsorios para el oficio de maitines, como de antífonas - aparece aquí en un modo I, el modo de la serenidad y de la paz. Se trasluce, sin embargo, en ella una gran desolación, un enorme patetismo. La melodía, sobria y sin apenas ornamentación, se estructura en dos frases: la primera hasta quasi non esset unctus oleo - imprecación con-

53 Cuenta también el I libro de Samuel que «cuando el mal espíritu atacaba a Saúl, David tomaba el arpa y tocabá. Saúl se sentía aliviado y se le pasaba el ataque del mal espíritu (I S. 16,23.)

54 I S. 18, 1.3

55 II S. 1, 25-26. 
tra los montes donde cayeron Saúl y Jonatán-; y la segunda hasta el final, en forma de alabanzas a los caídos. La intensidad de la pena es magníficamente expresada en la primera parte con el recurso a la parte más grave del modo, como si el sufrimiento humano sólo pudiera manifestarse desde la desolación más absoluta. Pero el dolor estalla en la segunda frase, quomodo ceciderunt, lanzándose más allá de su cuerda de composición, como si finalmente hubiera podido romper en amargos sollozos.

Cuán diferente se nos presenta la breve antífona Nigra sum, sed formosa. ${ }^{56}$ No hay aquí llanto ni dolor sino, por el contrario, la alegre manifestación de la vanidad de la amada que se ve correspondida por el amado.

IMAGEN N..$^{\circ} 10$

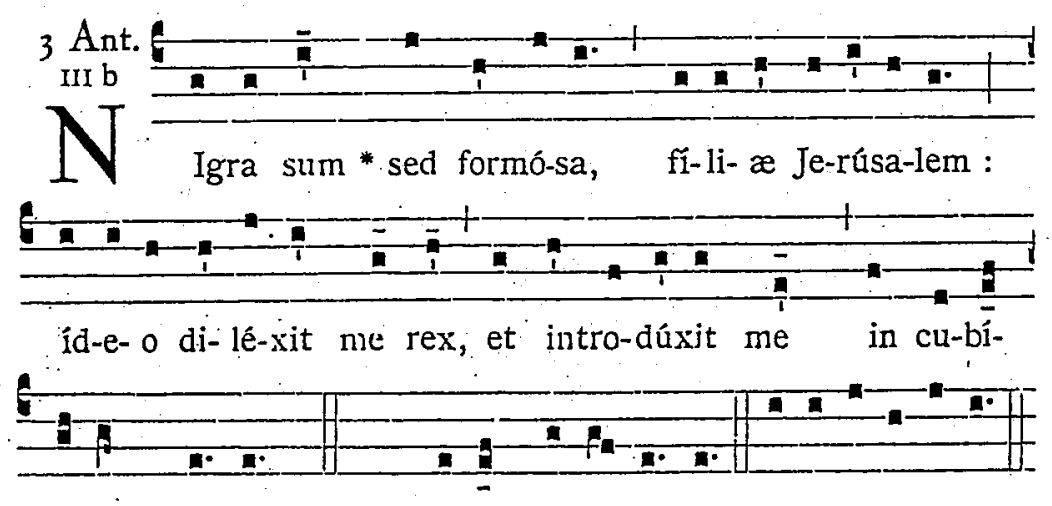

cu-lum tsu- um. T.P.† su-um, alle- lú- ia. E u o u a e.

Negra soy, pero hermosa, hijas de Jerusalén. Por eso me amó el rey, y' me introdujo en sus aposentos, alleluia.

El texto, tomado del Cantar de los Cantares, ${ }^{57}$ ha sido fuente de inspiración poética y musical para autores de todos los siglos. Un texto tan bello y sugerente, tan musical ya en su misma literalidad, había de desarrollarse en un modo III, «que revela gran impetuosidad, deseos ardientes (...) Revela con mayor rapidez que cualquier otro modo el afecto del corazón; es patético: en este modo varían felizmente los movimientos de fuerza, de grandiosidad, de nobleza y de dulzura». ${ }^{58}$ Recoge bien este comentario de Poisson la estética que encierra el dulce y firme cantar de la amada del rey:

56 AM. p. 707; Ct. 1, 5. Puede escucharse en Initiation au Chant Grégorien. Choeur des moines de l'abbaye de Kergonan. Studio SM, París, 1989.

57 Puede escucharse otro pasaje de este bellísimo Libro en su versión según el canto cisterciense en Chant Cistercien. Ensemble Organum. Dir. M. Pérès, Harmonia Mundi, Francia, 1992.

58 El texto es de Poisson, citado por Jeanneteau, J., op. cit., p. 314. 
«Soy morena, pero hermosa». El músico expresa esa frágil vanidad —que roza la coquetería一con el movimiento ondulatorio de la melodía, que descansa en $s i$-formosa-, luego en sol Jerusalem-, para pasar a continuación a $l a-$ rex-, y acabar finalmente en $m i-$ me, suum-. Esa «inestabilidad» sonora pretende reflejar el impreciso mundo que se apoya en algo tan efímero, y ciertamente tan necesario, como la belleza física.

\section{ACERCA DE OTROS REPERTORIOS}

Como se ha dicho, además de los repertorios para el solista, para la schola y para el coro, que reciben un tratamiento distinto según se útilicen en la misa o en el oficio divino, hay otra serie de piezas que se utilizaban a lo largo del año, en otros momentos de la vida litúrgica. Estaban entre ellas las bellísimas procesiones por los claustros de los monasterios, o a la fuente bautismal, 0 al cementerio, en las que, según exigía la ocasión, se entonaban los más diversos cantos procesionales. Ya, en el siglo IV, la peregrina española Egeria nos da detallada cuenta ${ }^{59}$ de las que se realizaban en Jerusalén, adonde ella había acudido en peregrinación. Los documentos de la época nos confirman que los hombres y mujeres de la Edad Media gustaban de estas manifestaciones, llenas de color y sonido, así como las dramatizaciones litúrgicas - conocidas como teatro litúrgico medieval一, de las que hablaremos más adelante.

La pieza de este repertorio que hemos elegido, el salmo 50 - Miserere- $-{ }^{60}$ pese a su abundante utilización en la liturgia ${ }^{61}$, no fue objeto de grandes y elaboradas creaciones musicales. Quizá su marcado sentido penitencial y su uso reiterado lo hacían más apto para un estilo más sobrio, como el que presentamos.

59 Arce, A., Itinerario de la virgen Egeria, Madrid, BAC, 1980. Vid., Prensa, L., «Hacia una recuperación de la Liturgia de la Orden del Santo Sepulcro», en Nassarre. Revista Aragonesa de Musicología, IX-1, Zaragoza, Institución «Fernando el Católico», 1993.

60 Cantus Selecti, Solesmis, Tournai, Desclé et Socii, 1949, p. 48-52; Salmo 50.

61 La Regla de san Benito (s. VI), en la que se inspiró la Iglesia para la ordenación de la liturgia hasta-el Concilio Vaticano II, pide que se cante todos los días del año, en el oficio de Laudes. Además, se utilizaba frecuentemente en otros momentos de la jornada, sobre todo en cuaresma, para las procesiones y otras celebraciones paralitúrgicas. 
IMAGEN N..$^{\circ} 11$

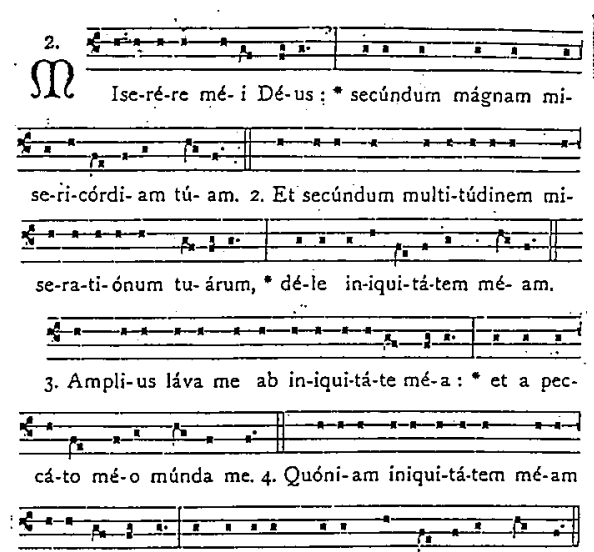

égo cognósco:" etpeccátum mé-um cóntra me est semper.
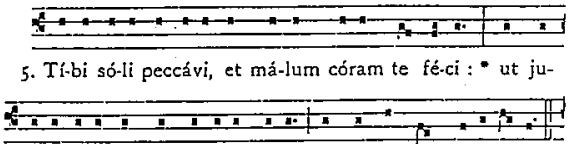

sti-fi-cé-ris in sermónibus tú-is, et víncas cum judi-cá-ris.

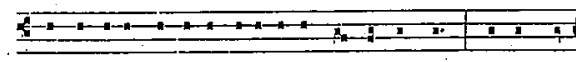

6. Ecce enim in in-iqui-tá-tibus concéptus sum :* et in pec-

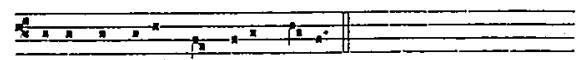

cá-tis concépit me mater mé- a.

Misericordia, Dios mío, por tu bondad; por tu inmensa bondad, borra mi culpa. Lava del todo mi delito; limpia mi pecado. Pues yo reconozco mi culpa, tengo sienpre presente mi pecado. Contra ti, contra ti sólo pequé; cometí la maldad que aborreces. En la sentencia tendrás razón; en el juicio resultarás inocente. Mira, en la culpa nací, pecador me concibió mi madre...

Una leyenda de Aragón ${ }^{62}$ describe el ambiente creado por el canto de este salmo. Aun reconociendo su legendario origen y lo exagerado de sus descripciones, recoge bien el mistérico mundo que envuelve al canto litúrgico. «Cuando los monjes llegaron al peristilo del templo, se ordenaron en dos hileras, y penetrando en él fueron a arrodillarse en el coro, donde con voz más levantada y solemne prosiguieron entonces los versículos del salmo. La música sonaba al compás de sus voces: aquella música era el rumor distante del trueno que, desvanecida la tempestad, se aleja murmurando; era el zumbido del aire que gemía en la concavidad del monte; era el monótono ruido de la cascada que caía sobre las rocas, la gota de agua que se filtraba... Todo esto era la música, y algo más que no puede explicarse ni apenas concebirse.

62 García Ruiz, G., Leyendas de Aragón, M.E. Editores, 1995, pp. 30-31. 
(...) Siguió la ceremonia; el músico, que la presenciaba absorto y aterrado, creía estar fuera del mundo real, vivir en esa región fantástica del sueño en que todas las cosas se revisten de formas extrañas y fenomenales.

Un sacudimiento terrible vino a sacarle de aquel estupor que embargaba todas las facultades de su espíritu. Sus nervios saltaron al impulso de una emoción fortísima; sus dientes chocaron (...) y el frío penetró hasta la médula de sus huesos.

Los monjes pronunciaban en aquel instante estas espantosas palabras del "Miserere": In iniquitatibus conceptus sum, et in peccatis concepit me mater mea. Al resonar este versículo y dilatarse sus ecos, retumbando la bóveda, se levantó un alarido tremendo, que parecía un grito de dolor arrancando a la humanidad entera por la conciencia de sus maldades...

Prosiguió el canto, ora tristísimo y profundo, ora semejante a un rayo de sol que rompe la nube oscura de la tempestad, haciendo suceder a un relámpago de terror otro relámpago de júbilo, hasta que, merced a una transformación súbita, la iglesia resplandeció bañada en luz celeste, las osamentas de los monjes se vistieron de sus carnes, una aureola luminosa brilló en derredor de sus frentes, se rompió la cúpula, y a través de ella se vio el cielo, como un océano de lumbre abierto a la mirada de los justos».

La febril imaginación del creador de esta leyenda nos transporta a un mundo mágico donde es más importante el texto que la melodía. No podía ser de otro modo, ya que la melodía de esta pieza procesional se mueve en un ámbito muy estrecho, pero capaz, a pesar de ello, de introducir en una sonoridad donde todo el artificio se basa en la insistente repetición. Podríamos recordar aquí esas otras melodías orientales que utilizan recursos parecidos para entrar en trance, para la elevación y el transporte místico. Decía Ustad Nishat Khan, ${ }^{63}$ músico hindú, que la base del canto gregoriano y de la música hindú Raag es únicamente espiritual y que, mediante las palabras y la música, pretende llegar a la divinidad como si de una meditación se tratara. De aquí que, más que expresar emociones y colores, quiera inducir a la reflexión y que la melodía pase a un segundo plano, para que el alma pueda saborear cuanto la voz declama.

Entramos, finalmente, en la última etapa de nuestro viaje iniciático. ¿Cómo no mencionar en estas páginas el deslumbrante y bellísimo mundo del drama litúrgico? En él se alían, en majestuosa amalgama, los sonidos en forma de diálogo cantado, los gestos como reclamo visual, los lucernarios para resaltar los acontecimientos escenificados y las ricas vestiduras para embellecer la acción. En los siglos XI-XIII los compositores se afanan en la creación de formas de expresión hasta ese momento desconocidas o poco utilizadas. De su labor creadora dan testimonio los dramas de Las vírgenes sabias y necias, Los profetas, La visitatio Sepulchri, Daniel, Los tres clérigos, El judio robado, El hijo de Gedrón, La adoración de los magos, Las santas mujeres en el sepulcro, Los discípulos de Emaús, La conversión de san Pablo, La resurrección de Lázaro. ${ }^{64}$

Estas escenificaciones, auténtico teatro, se llevaban a cabo en el interior de la iglesia, ora en el presbiterio, ora en las naves laterales, ora en el antecoro. Dependiendo de la acción a desarrollar,

63 Este músico ha grabado recientemente un precioso disco, donde utiliza las melodías gregorianas como base pára su acompañamiento o improvisación con el Sitar. Puede escucharse en Meeting of Angels. Ensemble Gilles Binchois; Sitar: Ustad Nishat Khan. Amiata Records, 1996.

64 Vid. Coussemaker, E., Drames liturgiques du Moyen Âge. Texte et musique, Genève, Slatkine Reprints, 1975. 
los actores —clérigos o monjes de sus respectivas iglesias - se movían entre la muchedumbre, subían hacia el presbiterio o se encondían detrás del altar. Todo era legítimo para producir la admiración de los asistentes, que, maravillados, asistían al espectáculo desde las naves y, según cuentan los códices de la época, prorrumpían en aplausos al finalizar, tan grande era la emoción contenida hasta entonces. De toda esa belleza, plástica y musical, podrían dar testimonio los muros de las iglesias románicas y góticas donde se desarrollaron a lo largo de los siglos.

El ejemplo escogido corresponde a un fragmento del drama Los discípulos de Emaús. ${ }^{65}$

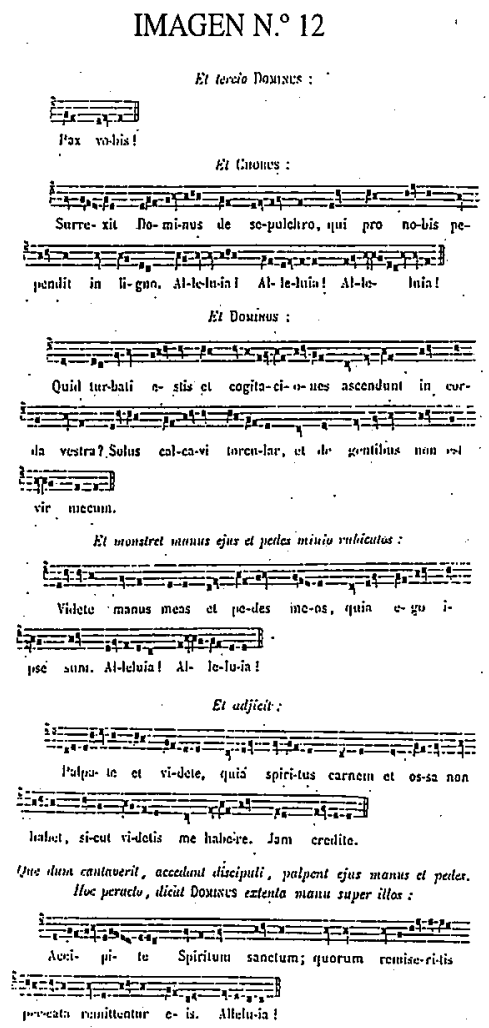

Cristo: ¡Paz a vosotros! Coro: Ha resucitado el Señor del sepulcro, el que por nosotros estuvo colgado del madero. ¡Aleluya, aleluya, aleluya! Cristo: ¿Por qué estáis tan turbados y qué pensamientos agitan vuestros corazones? Yo pise solo el lagar y de entre las gentes no hubo ni un solo varón conmigo. Ved mis manos y mis pies: soy yo, el mismo. ¡Aleluya, aleluya! Palpad y ved que un espiritu no tiene canne y huesos, como véis que tengo yo. Creed ya. Recibid el Espiritu Santo: a quiénes perdonéis los pecados les serán perdonados. ¡Aleluya!

65 Ms. de la abadía de St. Benoît-sur-Loire. Biblioteca de Orléans (Francia). Puede verse este drama en el vídeo Tropos - Secuencias - Teatro litúrgico medieval, a cargo de la Schola Gregoriana Domus Aurea, con la dirección de Luis Prensa, y al órgano, Jesús Gonzalo. Institución «Fernando el Católico» (Excma. Diputación de Zaragoza), Zaragoza, CPA, 1997. 
Es éste uno de los «actos» de que se compone el drama: la aparición de Jesús a los apóstoles. Los intérpretes son solistas-actores, que han de recordar en todo momento las palabras de san Isidoro de Sevilla: «Cuán importante es que el cantor se distinga e incluso destaque por su talento, con el fin de acrecentar el placer de quienes le escuchan (...) Su voz no debe ser áspera, ronca o disonante, sino cantarina, dulce, limpia, aguda, sonora y de melodía apropiada a la santa religión. Que no declame como en el teatro, sino que haga prueba de una sencillez cristiana en su canto (...) e imprima a los oyentes una gran compunción». ${ }^{66}$ Como sugiere san Isidoro, hay una gran diferencia entre el declamar de los actores de teatro y los cantores de la liturgia: los primeros actúan, los segundos viven. La diferencia no es pequeña. En este repertorio la belleza sonora se alía a la plástica, al color, al movimiento, en un conjunto ordenado de elementos estéticos que tratan de suscitar en el corazón del oyente una respuesta emocionada. Mucho después Wagner afirmaba lo mismo de la ópera.

¿Cómo no conmoverse hasta las lágrimas al escuchar Videte manus meas et pedes meos, mientras Cristo les ofrece la visión de sus manos ensangrentadas? ¿Cómo no emocionarse ante la firmeza del palpate et videte? La melodía, aquí y siempre, al servicio de la palabra; la melodía, aquí, al servicio de la acción dramática. Y todo - palabra, música, acción - en apoyo de la estética global, a través de la mirada. Decía, sin embargo, Muhyiddin Ibn Arabi que no corresponde al ojo el deleite, sino al corazón, y que la belleza es sólo el medio por el cual se llega a lo anhelado. ${ }^{67} \mathrm{Y}$ es cierto. El ojo es la puerta a través de la cual se introduce la belleza en el corazón, la ventana por donde entran las imágenes sonoras del drama, pero es finalmente esa misteriosa belleza la que permite tomar definitiva posesión de lo largamente deseado.

\section{EPÍLOGO}

En nuestro iniciático viaje al interior, hemos atravesado oscuros e impetuosos ríos musicales, a través de cuyas aguas hemos podido vislumbrar siquiera un asomo de la estética del dolor, de la desazón, de la desolación (Responsorio gradual: Sederunt). Sufrimiento y dolor, sí, pero bellamente expresado en música. Hemos cruzado también por jardines salvajes y enmarañados, en cuya espesura ha resonado el reproche (Antifona de comunión: Tanto tempore) y el misterio (Antífona de Introito: terribilis est). Hemos bordeado confusos precipicios, al final de los cuales se asomaba la refulgente luz del éxtasis (Salmo Miserere). Hemos alcanzado las cumbres más encrespadas, y en ellas hemos sido transfigurados (Alleluia, Pascha nostrum). Hemos hallado reposo en los magníficos palacios del rey, donde hemos escuchado la voz de su amada (Nigra sum, sed formosa). Y, finalmente, en las iglesias abaciales hemos asistido al esplendor del teatro que, a fuerza de vivirse, se confunde con la misma vida (Los discípulos de Emaús).

¡Cuánta es la belleza desplegada! ¡Cuán inmensa la sabiduría musical de los hombres y mujeres del medievo que supieron transmitirla mediante el artificio sonoro! Si, como decíamos más arriba, la estética musical se propone favorecer y desarrollar no la habilidad técnica, sino la inteligen-

66 San Isidoro de Sevilla, De ecclesiasticis officiis, II, cap. IX.

67 Muhyiddin Ibn Arabi. Música en la Aljafería. Homenaje a Avempace, Zaragoza, Aragón LCD Prames, 1999. 
cia y la comprensión de la obra artística en sí misma, la música litúrgica medieval es el fabuloso mundo donde hallar todas y cada una de las cualidades que definen lo bello. Y si la belleza es la cualidad que más amable hace la vida, en la belleza puede encontrarse el reclamo que hace al hombre más íntegro: «El sonido musical transporta, como si estuviera animado, las emociones y los pensamientos del alma del cantor o el intérprete a las almas de los oyentes (...) por el movimiento del aire mueve al cuerpo: por el aire purificado excita el espíritu aéreo que es el vínculo de cuerpo y alma; por significado trabaja en la mente. Finalmente, por el propio movimiento del aire sutil penetra con fuerza: por su temperamento fluye suavemente; por la conformidad de su cualidad nos inunda con un maravilloso placer; por su naturaleza, tanto espiritual como material, a la vez atrapa y reclama como propio al hombre en su integridad».68

Luis Prensa Villegas

Conservatorio Superior de Música

San Miguel, 32

50001 Zaragoza

68 De Marsilio Ficino (s. XV) Spiritual and demonic magic from Finicio to Campanella, Londres, Warburg Institute, 1958, citado en Rowell, L., op. cit., p.77. 